Research paper

\title{
Bolătău sediment record - Chronology, microsedimentology and potential for a high resolution multimillennial paleoenvironmental proxy archive
}

\author{
Marcel Mîndrescu a , Alexandra Németh ${ }^{\text {b }}$, Ionela Grădinaru a , Árpád Bihari ${ }^{\text {, }}$ \\ Tibor Németh ${ }^{\mathrm{b}}$, József Fekete ${ }^{\mathrm{b}}$, Gábor Bozsó ${ }^{\mathrm{d}}$, Zoltán Kern ${ }^{\mathrm{b}, \text { * }}$ \\ a Department of Geography, Ștefan cel Mare University, Str. Universitatii nr.13, 720229, Suceava, Romania \\ ${ }^{\mathrm{b}}$ Institute for Geological and Geochemical Research, Research Centre for Astronomy and Earth Sciences, MTA, Budaorsi ut 45, H-1112, Budapest, Hungary \\ ${ }^{\mathrm{c}}$ Hertelendi Laboratory of Environmental Studies, Institute for Nuclear Research, MTA, Bem ter, 18/c, H-4026, Debrecen, Hungary \\ d Department of Mineralogy, Geochemistry and Petrology Faculty of Science and Informatics, University of Szeged, Egyetem street 2., H-6722, Szeged, \\ Hungary
}

\section{A R T I C L E I N F O}

\section{Article history:}

Received 27 January 2015

Received in revised form

9 October 2015

Accepted 14 October 2015

Available online 1 December 2015

\section{Keywords:}

Paleolimnology

Holocene

Lacustrine chronology

Laminated archive

Stable carbon isotope

Carpathians

\begin{abstract}
A B S T R A C T
Finely laminated sediment records have been studied from a small landslide-dammed lake (Bolătău) located in Bukovina, Romania. An age-depth model for the Bolătău sediment record was established based on 8 AMS radiocarbon dates from terrestrial macrofossils and the double peaks of the ${ }^{137} \mathrm{Cs}$ flux (i.e. mid-1960s: global fallout maximum; 1986: Chernobyl accident). The onset of the lacustrine sedimentation is estimated to $\sim 5-6.5 \mathrm{ka}$ while the landslide event can be constrained by $\sim 6.8-7 \mathrm{ka}$ as an inferior age estimate. The laminated structure is interpreted as organic and clastic type varvite at the lower and upper part of the core, respectively. Major fluctuations found in the coarsely sampled (5 cm) stable carbon isotope data showed remarkable correspondence with nearby palynological records and a lacustrine $\delta^{13} \mathrm{C}$ record. It suggests that the sediment record preserves environmental signals with a broader regional relevance. The established timescale provides the necessary chronological basis of the records from Lake Bolătău for further analysis.
\end{abstract}

(C) 2015 Elsevier B.V. All rights reserved.

\section{Introduction}

Reconstructing past climate conditions throughout ample time frames is becoming increasingly necessary in order to place current climate changes into a broader context. Lacustrine sediments typically integrate and preserve environmental signals into their structure and composition, therefore geochemical and sedimentological analyses of these archives have become an instrumental tool for monitoring environmental change by providing an important longer-term temporal perspective and enhancing environmental assessment (e.g., Smol, 1992; Anderson and Battarbee, 1994; Anderson, 1995; Smol, 2008; Akinyemi et al., 2013). A wide range of lake sediment-based analysis techniques pertaining to several

\footnotetext{
* Corresponding author. Institute for Geological and Geochemical Research, Research Centre for Astronomy and Earth Sciences, MTA, Budaörsi ut 45., H-1112, Budapest, Hungary.

E-mail address: kern@geochem.hu (Z. Kern).
}

research fields (i.e. geochemistry, geology, botany etc.) are currently employed for understanding the dynamics of local and regional climate over various time scales (Smol et al., 2001a,b; Birks and Birks, 2006).

Moreover, a robust age model is an essential prerequisite for understanding paleoclimate signals, for comparison of different records, and for resolving the successions and timing of different events detected in the sedimentary sequence.

Whereas the potential of mountain lake sediments for providing accurate climate change indicators has long been recognized and thoroughly studied, lakes throughout the Carpathian region from Romania, Slovakia and Ukraine remain as yet 'seriously underinvestigated although they would be ideal objects of paleolimnological work', as concluded by Buczkó et al. (2009). Against this background, the potential for climate reconstructions of landslidedammed lakes (such as Bolătău and Iezer in the northern area of the Eastern Romanian Carpathians) which are rather scarce (Cohen, 2003) was only recently acknowledged and came to the attention of paleolimnological research in Romania (Mindrescu et al., 2010a,b; 
2013).

Of the two, Lake Bolătău was first reported in the literature as late as the 1960s (Georgescu and Georgescu, 1964, brief mention regarding lake origin); however, it was completely overlooked in terms of research until recently (Mindrescu et al., 2010a,b). Along with lakes Iezer and Paşcanu (Georgescu and Georgescu, 1964), located in the nearby mountain area under largely similar geological conditions which favoured landslide damming of the respective streams, Bolătău is part of the 'Bukovinian Millennial Lakes' triangle.

The study of historical and cartographical data and preliminary assessments on sediments extracted from Lake Bolătău resulted in two hypotheses: (i) the lake is likely significantly older than previously thought and (ii) the sediments are varved and suitable for multi millenial-scale paleoenvironmental reconstructions, both of which we wanted to test.

Finally, we wanted to test the potential of Bolătău lacustrine sediment archive for future paleoclimate studies and acquire a preliminary impression on the achievable record which would guide subsequent detailed geochemical studies; to this purpose, stable carbon isotope composition of the bulk carbonate-free sediment was analysed and compared to coeval terrestrial records available from the broader region.

\section{Materials and methods}

\subsection{Lake description and sampling}

Lake Bolătău (1137 m a.s.l.) is located in Obcinele Bucovinei, an outer subdivision of the Eastern Romanian Carpathians (Fig. 1), which rise to an elevation of around $1300 \mathrm{~m}$ a.s.l. in the vicinity of the lake catchment. The lake formed in the southwestern area of Obcina Feredeului, in the drainage basin of a tributary of river Moldova on Bolătău stream (also known as Holohoşca on the lower course). As the toponym Bolătău (literally, pond or puddle, often with marshy characteristics) is rather common in the local and regional toponymy (Grădinaru et al., 2012), the lake is presently referred to in the literature as Lake Bolătău-Feredeu (Mindrescu et al., 2013).

The geology of the study area comprises Cretaceous ('Black shale formation') and Paleogene flysch formations pertaining to the Audia Nappe (Săndulescu, 1984). The stratigraphy consists mainly of sequences of glauconitic sandstones, red, green and striped clays, black marly shales etc. The lake catchment overlies truncated edges of near vertical folded flysch strata which were subjected to weathering and erosion, thus resulting in increased susceptibility to landsliding under triggering conditions, i.e. heavy rainfall, earthquakes etc. (Georgescu and Georgescu, 1964). Consequently, Lake Bolătău was created by the obstruction of a deep and narrow stream valley by landsliding of the surrounding Cretaceous flysch, which displaced roughly $9 \mathrm{M} \mathrm{m}^{3}$ of rock. Currently the maximum depth of the lake ranges up to $5.4 \mathrm{~m}$; the lake has a small inflow and an outflow stream.

The lake catchment (approx. 30 ha, see Table 1) is entirely covered by coniferous forest comprising to a large extent of Picea abies which dominates the landscape at the lake site.

Whereas the regional climate falls into the temperate continental type, the site located nearby Cîmpulung Moldovenesc (CM $642 \mathrm{~m}$ a.s.l.) and Rarău Mts (1572 m a.s.l.) meteorological stations (Fig. 1) exhibits some distinctive features, particularly in terms of annual precipitation amounts ranging from $696 \mathrm{~mm}(\mathrm{CM})$ to $902 \mathrm{~mm}$ (Rarău), 73\% of which fall during the warm season (April-September). Rarău station and the surrounding area are also included in the zone of maximum duration of rainfall within the Romanian territory (Rusu, 2002). The mean annual temperature is
$6.4{ }^{\circ} \mathrm{C}\left(16.5^{\circ} \mathrm{C}\right.$ in July and $-5.2{ }^{\circ} \mathrm{C}$ in January, from 1934 to 1987). Moreover, $41 \%$ (CM) to $48 \%$ (Rarău) of the duration of a year consists of days with temperatures below $0{ }^{\circ} \mathrm{C}$, typically from October to April (Rusu, 2002) when the conditions are met for the lake to freeze. Depending on the temperature regime during late autumn, freezing may be delayed until December, as was often the case during the past decade (anecdotal data).

The sediment cores were retrieved in April 2013 using both a Russian corer and a gravity corer from the frozen surface of the lake (see Supplementary FigS1). The distance between the cores were less than $1 \mathrm{~m}$ since they were extracted from the same slot cut in the ice. The gravity core preserved the water-sediment interface intact; however the preservation of the unconsolidated sediment at the top of the Russian core is known to be imperfect and a couple of centimetres of sediment lost is conceivable. However, when characteristic stratigraphic levels were compared between the overlapping sections of the cores we found very good agreement $(<1 \mathrm{~cm})$ without any systematic shift, therefore the depth scale of the Russian core was used without modification subsequently. The Russian corer extracted $0.6 \mathrm{~m}$ long sediment units. The resulting cores (Russian corer: $401 \mathrm{~cm}$, and gravity corer: $66 \mathrm{~cm}$ beneath the water-sediment interface) were visually inspected on site, described, photographed and sectioned at intervals of $1.0 \mathrm{~cm}$ into pre-labelled plastic bags. The samples were weighed and kept refrigerated before they were dried at $40^{\circ} \mathrm{C}$.

The occurrence of an apparent sharp change in the laminated lacustrine sediment at the depth of $387 \mathrm{~cm}$ was documented which indicated that the landslide body deposit was penetrated by the Russian corer at that depth in the coring point.

\subsection{Microsedimentological study}

Four sections (depth ranges: $72-73 \mathrm{~cm}, 178-179 \mathrm{~cm}, 298-299$ $\mathrm{cm}, 352-353 \mathrm{~cm}$ ) were selected for microsedimentological analysis. Dried sediment samples (soaked with Araldite) and petrographic thin sections have been prepared. The microsedimentological sections were studied by polarization microscopy using a Nikon Eclipse E600 Pol microscope and attached Spot insight camera.

Backscattered electron (BSE) images and elemental composition of carbon coated sections were studied by a JEOL Superprobe 733 electron microprobe with INCA Energy 200 Oxford Instrument Energy Dispersive Spectrometer. The analytical circumstances were: acceleration voltage: $20 \mathrm{keV}$, beam current: $6 \mathrm{nA}$, count time: $60 \mathrm{~s}$ for the spot measurement and $5 \mathrm{~min}$ for line scan analysis.

The mineralogical composition was determined by X-ray powder diffraction (XRD) analysis on oriented samples. XRD analysis was made on a Philips PW1710 type X-ray diffractometer with the following instrument parameters: $\mathrm{CuK} \alpha$ radiation, graphite monochromator, $45 \mathrm{kV}$ acceleration voltage, $35 \mathrm{~mA}$ intensity, $1^{\circ}$ divergence slit.

Polarization and SEM microscopy, and XRD analyses were carried out at the Institute for Geological and Geochemical Research, Research Centre for Astronomy and Earth Sciences, MTA (Budapest, Hungary).

\subsection{Gamma-spectrometry for ${ }^{137}$ Cs activity}

Radiocaesium $\left({ }^{137} \mathrm{Cs}, \mathrm{t}_{1 / 2}=30.07 \mathrm{yr}\right)$ is originally absent in nature and has been produced and released by anthropogenic processes. Its most important global environmental source was the fallout from atmospheric thermonuclear weapon tests (from 1954 to 1963 ) which peaked in the early 1960s and declined rapidly in terms of intensity after the Nuclear Test Ban Treaty in 1963. Afterwards, the majority of Eurasia was affected by a subsequent 

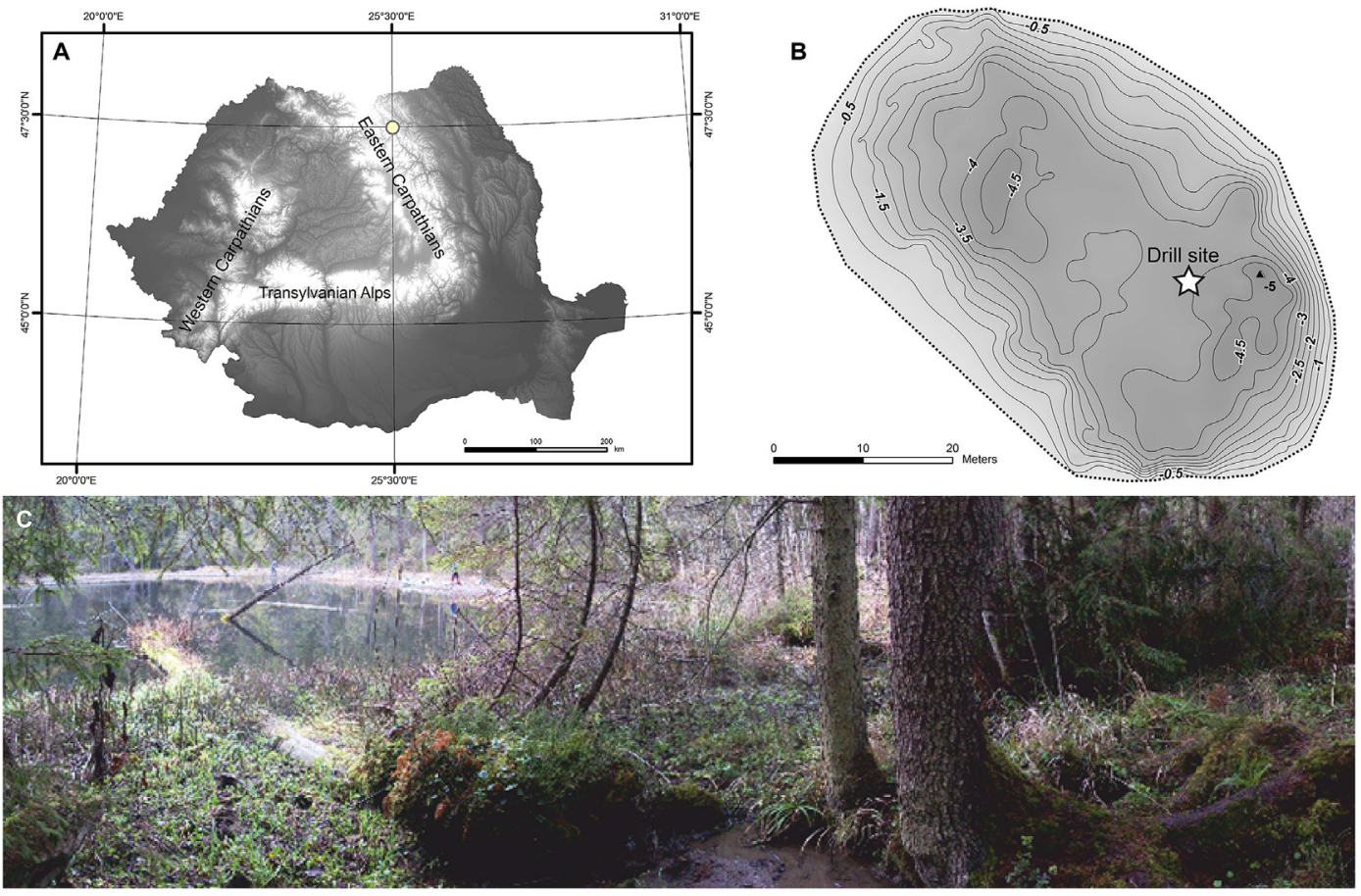

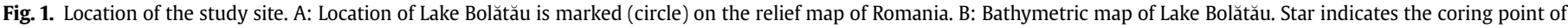
April 2013. C: Landscape of the lakeshore.

Table 1

Lake and catchment characteristics.

\begin{tabular}{ll}
\hline Parameter & Lake Bolătău-Feredeu \\
\hline Latitude, N & $47^{\circ} 37^{\prime} 19^{\prime \prime}$ \\
Longitude, E & $25^{\circ} 25^{\prime} 49^{\prime \prime}$ \\
Altitude (m a.s.l.) & 1137 \\
Catchment area (ha) & 29.57 \\
Lake area in 1981 (cartographic data) $\left(\mathrm{m}^{2}\right)$ & 2280 \\
Lake area in 2010 (GPS data) $\left(\mathrm{m}^{2}\right)$ & 2350 \\
Water volume in 2010 $\left(\mathrm{m}^{3}\right)$ & 5699 \\
Max. water depth (m) & 5.4 \\
Sediment thickness (m) at coring point of April 2013 & 3.87 \\
Water depth (m) at coring point of April 2013 & 4.00 \\
pH & 6.8 \\
\hline
\end{tabular}

deposition of ${ }^{137} \mathrm{Cs}$ due to the accident of Chernobyl Nuclear Power Plant (26 April 1986) (IAEA, 1991; De Cort et al., 1998). The depthdistribution of fallout-derived ${ }^{137} \mathrm{Cs}$ is widely used to establish the recent (max. 6 decades) chronology of sediment cores retrieved from various depositional systems.

The radiocaesium $(\mathrm{E} \gamma=661.6 \mathrm{keV})$ contents of sediment samples have been measured with two gamma-spectrometry systems: i) Canberra-Packard BE5030-7915-30ULB thin-windowed broadenergy HPGe detector (48\% relative efficiency) and ii) Canberra GC10021-7915-30ULB large crystal HPGe detector (101\% relative efficiency). Both detectors are equipped with DSA2000 multichannel analyser and Genie-2000 spectroscopy software (incl. Gamma Analyses module and Interactive Peak Fit module). Both the samples and the calibration sources have been packed into $90 \mathrm{~mm}$ diameter Petri dishes and have been placed directly on the detector cap for measurement. Efficiency calibrations have been performed using IAEA-385 sediment CRM. Efficiency calibration curves include self-attenuation and coincidence correction.

The samples have been counted for at least $24 \mathrm{~h}$ on each system. The final results for each sample are calculated as the weighted average of the results from the two systems but the uncertainty from the calibration source is taken into consideration.

\subsection{AMS radiocarbon analysis}

Nine organic macro remains have been separated from the cores for radiocarbon analysis. Eight samples were picked out from the lacustrine sediment profile ( 1 from the gravity core, 7 from the Russian core) while one piece of wood was found in the landslide mass reached after penetration of the lacustrine deposit (Table 1).

The samples were prepared by the conventional acid-alkali-acid (AAA) treatment. Measured targets were prepared using a sealedtube graphitization method (Molnár et al., 2013a; Rinyu et al., 2013).

The ${ }^{14} \mathrm{C} /{ }^{12} \mathrm{C}$ ratio and its ${ }^{13} \mathrm{C} /{ }^{12} \mathrm{C}$ correction were measured by accelerator mass spectrometry on the EnvironMICADAS ${ }^{14} \mathrm{C}$ facility in the Hertelendi Laboratory of Environmental Studies in Debrecen, Hungary (Molnár et al., 2013b). Measurement time and conditions were set to collect at least 200,000 net counts for every single target in case of a modern sample. The overall measurement uncertainty for a modern sample is $<3 \%$, including normalization, background subtraction, and counting statistics.

The conventional radiocarbon ages were calculated according to Stuiver and Polach (1977) using the Libby half-life (5568 years) and corrected for isotope fractionation using the AMS measured ${ }^{13} \mathrm{C} /{ }^{12} \mathrm{C}$ ratio which accounts for both natural and machine fractionation.

\subsection{Calibration and age-depth modelling}

Calibration of ${ }^{14} \mathrm{C}$ dates to calendar years and age-depth modelling were performed using P_Sequence function from the OxCal v.4.2 (Bronk Ramsey, 2009) program in conjunction with the Northern Hemisphere IntCal13 (Reimer et al., 2013) dataset. Calibrated ages are reported with two standard deviations $(2 \sigma)$.

We assumed a core-top age of AD 2012, the last entire year preceding core collection. Two distinct ${ }^{137} \mathrm{Cs}$ peaks were found in the uppermost $20 \mathrm{~cm}$ of the sediment core and used as independent time markers to validate the poorly constrained upper section of the ${ }^{14} \mathrm{C}$ based age-depth model (Appleby, 2008). 
As an exception, the ${ }^{14} \mathrm{C}$ date obtained from the deepest sample (DeA-2636) has been calibrated separately following the classical single-date calibration scheme since this sample does not belong to the lacustrine sediment profile.

\subsection{Stable carbon isotope composition of the lacustrine profile}

To test the potential of the geochemical signals of the sediment record we decided to perform a pilot study on stable carbon isotope composition. Since both the XRD results (3 samples) and the visual $\mathrm{HCl}$ solution test made on 5 additional samples selected randomly along the core indicated carbonates are absent in the sediment bulk sediment samples were subsampled for ${ }^{13} \mathrm{C} /{ }^{12} \mathrm{C}$ analysis without carbonate removal.

For bulk $\delta^{13} \mathrm{C}$ analysis aliquots (100 $\mathrm{mg}$ in duplicates) were oxidized with $\mathrm{CuO}$ in evacuated and flame-sealed Pyrex tubes at $480{ }^{\circ} \mathrm{C}$ based on the method of Sofer (1980). The evolved $\mathrm{H}_{2} \mathrm{O}$ and $\mathrm{CO}_{2}$ were separated online by cold traps using liquid nitrogen and ethylalcohol cooled below $-80{ }^{\circ} \mathrm{C}$. The ${ }^{13} \mathrm{C} /{ }^{12} \mathrm{C}$ ratios were determined using a Finnigan MAT delta $\mathrm{S}$ mass spectrometer (Thermo Fisher Scientific, Inc., Waltham, MA, USA). The results are given in the conventional $\delta$ value $\left(\delta=\left(R_{\text {sample }} / R_{\text {standard }}-1\right)^{*} 1000\right.$, where $R_{\text {sample }}$ and $\mathrm{R}_{\text {standard }}$ are the ${ }^{13} \mathrm{C} /{ }^{12} \mathrm{C}$ ratios in the sample and standard, respectively (McKinney et al., 1950) relative to V-PDB (Coplen et al., 2006), in \%o. Based on sample reproducibility and differences in $\delta^{13} \mathrm{C}$ values obtained for standards (IAEA CH-7 and laboratory reference) from their theoretical values, the results are accurate at $< \pm 0.1 \%$ for $\delta^{13} \mathrm{C}$.

\section{Results}

\subsection{Microsedimentology}

Alternating laminae of allochthonous clay/silt and organic material $(\mathrm{OM})$ rich layers were visible on the petrographic thin sections. The thickness of these couplets varies on a scale from $200 \mu \mathrm{m}$ to $\mathrm{mm}$. The quantity and size of allochthonous clasts is highly variable: in certain couplets only a thin, silty lamina is visible between the two OM rich layers (Fig. 2A,B,C) while others consist of thicker fine sand laminae (Fig. 2 D, E, F). The boundary between the clastic and OM rich laminae is often gradational while the top of the couplets is sharply separated from the clastic bottom of the next one (Fig. 2D).

Thicker (500 $\mu \mathrm{m}$ to $\mathrm{mm}$ ), normally, or sometimes also inversely graded laminae are intercalated with the coupled laminae (Fig. 2H,I). Sometimes they are distinguishable even macroscopically due to their white or greyish clay cap (Fig. 2G).

Two mineral phases attracted the attention during the detailed inspection of the sediment samples: a bluish powdery or microcrystalline aggregate and an opaque one with metallic luster. XRD analyses of two separated samples helped to identify vivianite and pyrite for the bluish and the metallic phase, respectively (Fig. 3A,D).

Vivianite is macroscopically visible only under $306 \mathrm{~cm}$ in the core. It is abundant as microcrystalline filling in the cavities of organic material (e.g. in seeds) (Fig. 3E,F).

Pyrite occurs in two different forms: it is also abundant in OM rich layers as micro-botryoidal cavity filling, however it often forms framboids in the sediment with the usual diameters of 5-10 $\mu \mathrm{m}$ (Fig. 3B,C). Some larger (with 30-35 $\mu \mathrm{m}$ diameter) framboids are attached to organic pellets. The space around them is often filled by micro-botryoidal aggregates; these are usually smaller than $1 \mu \mathrm{m}$ and based on their shape and location they were clearly formed after the larger framboids. Smaller ones $(\mathrm{d} \sim 10-15 \mu \mathrm{m})$ can be also found separately in the clay or silt. These particles are not associated with organic material.

\subsection{Chronology of the Bolătău sediment}

The measurement and calibration results of the radiocarbon analyses are presented in Table 2. The calibrated age of the wood fragment obtained from the underlying landslide body is 6947-6783 cal BP. It provides an inferior limit for the age model and a time constraint for the landslide event of the basin genesis.

Two distinct ${ }^{137} \mathrm{Cs}$ peaks were found at $6-7 \mathrm{~cm}$ and $11-12 \mathrm{~cm}$ depth interval (Fig. 4.). The deposited inventory of bomb-derived fallout of ${ }^{137} \mathrm{Cs}$ has been about $5-7 \mathrm{kBq} / \mathrm{m}^{2}$ for sites with medium latitudes and continental climate (Ritchie and McHenry, 1990). The radiocaesium release of the accident of the Chernobyl NPP affected the areas far off according to short-term plume trajectories and weather conditions (De Cort et al., 1998). Regarding the territory of Romania the highest deposits were found in Transylvania ( $>80 \mathrm{kBq} /$ $\mathrm{m}^{2}$ ) while measured average deposition in Suceava following the event was $13.5 \mathrm{kBq} / \mathrm{m}^{2}$ (Cosma, 2002).

This double peak pattern of ${ }^{137} \mathrm{Cs}$ profiles is quite typical for the undisturbed sediment profiles in the broader region (Begy et al., 2009, Blebea-Apostu et al., 2012; Alhajji et al., 2014). Thus, in line with the usual practice, the higher and the deeper ${ }^{137} \mathrm{Cs}$ peak horizons were assigned to AD 1986 and AD 1964, respectively.

The OxCal agreement indices for the individual ${ }^{14} \mathrm{C}$ samples ranged from 74.9 to $103.6 \%$ (Table 2), while the overall series OxCal agreement index $\left(A_{\text {modell }}=93 \%\right)$ proved to be satisfactory.

The established age model allowed for estimating the achieved temporal resolution corresponding to the $1 \mathrm{~cm}$ sampling units (Supplementary Fig. S2). The $1 \mathrm{~cm}$ samples integrate 6-7 years over the uppermost $50 \mathrm{~cm}, 20-22$ years between 170 and $300 \mathrm{~cm}$ depth interval while a 10-15 years resolution is obtained over the rest of the core. As a consequence, the present sampling strategy offers (sub)decadal resolution for the last 1200 years, while the finest

Table 2

Radiocarbon activities and calibration results of the analysed samples from the Bolătău sediment profile.

\begin{tabular}{|c|c|c|c|c|c|c|}
\hline Lab code $^{\mathrm{a}}$ & Depth $(\mathrm{cm})$ & C-14 pMC abs. & Conv. C-14 age (yrs BP) & Unmodelled age (cal BP) & Modelled (cal BP) & $\mathrm{A}(\%)^{\mathrm{b}}$ \\
\hline DeA-2637 & $26-27^{c}$ & $98.77 \pm 0.31$ & $100 \pm 25$ & $264-219$ or $143-23$ & $254-219$ or $145-27$ & 100.5 \\
\hline DeA-2638 & $41-42$ & $97.92 \pm 0.30$ & $169 \pm 25$ & $\begin{array}{l}288-254 \text { or } 225-136 \text { or } \\
115-106 \text { or } 100-73 \text { or } 34-<0\end{array}$ & $\begin{array}{l}290-252 \text { or } 225-165 \\
\text { or } 157-141\end{array}$ & 103.6 \\
\hline DeA-2639 & $50-51$ & $95.35 \pm 0.31$ & $383 \pm 26$ & $506-427$ or $378-320$ & $392-315$ & 74.9 \\
\hline DeA-2640 & $61-62$ & $96.1 \pm 0.30$ & $320 \pm 25$ & $463-306$ & $468-350$ & 100.4 \\
\hline DeA-2641 & $126-127$ & $86.11 \pm 0.27$ & $1201 \pm 25$ & $1225-1212$ or $1183-1060$ & $1230-1210$ or $1184-1062$ & 98.3 \\
\hline DeA-2642 & $156-157$ & $80.44 \pm 0.27$ & $1749 \pm 27$ & $1718-1569$ & $1715-1591$ or $1586-1570$ & 101.8 \\
\hline DeA-2643 & $170-171$ & $79.43 \pm 0.27$ & $1850 \pm 27$ & $1865-1715$ & $1865-1720$ & 100.3 \\
\hline DeA-2644 & $305-306$ & $60.73 \pm 0.22$ & $4006 \pm 29$ & $4527-4419$ & $4525-4419$ & 99.8 \\
\hline DeA-2636 & $\begin{array}{l}\text { Wood from the } \\
\text { landslide }\end{array}$ & $47.28 \pm 0.18$ & $6018 \pm 31$ & $6947-6783$ & - & - \\
\hline
\end{tabular}

\footnotetext{
a Individual laboratory code of Debrecen radiocarbon lab for samples measured with accelerator mass spectrometry (Molnár et al., 2012).

b Individual agreement percent of the Bayesian age-depth model (see Fig. 5).

c Depth beneath the top of the gravity core.
} 

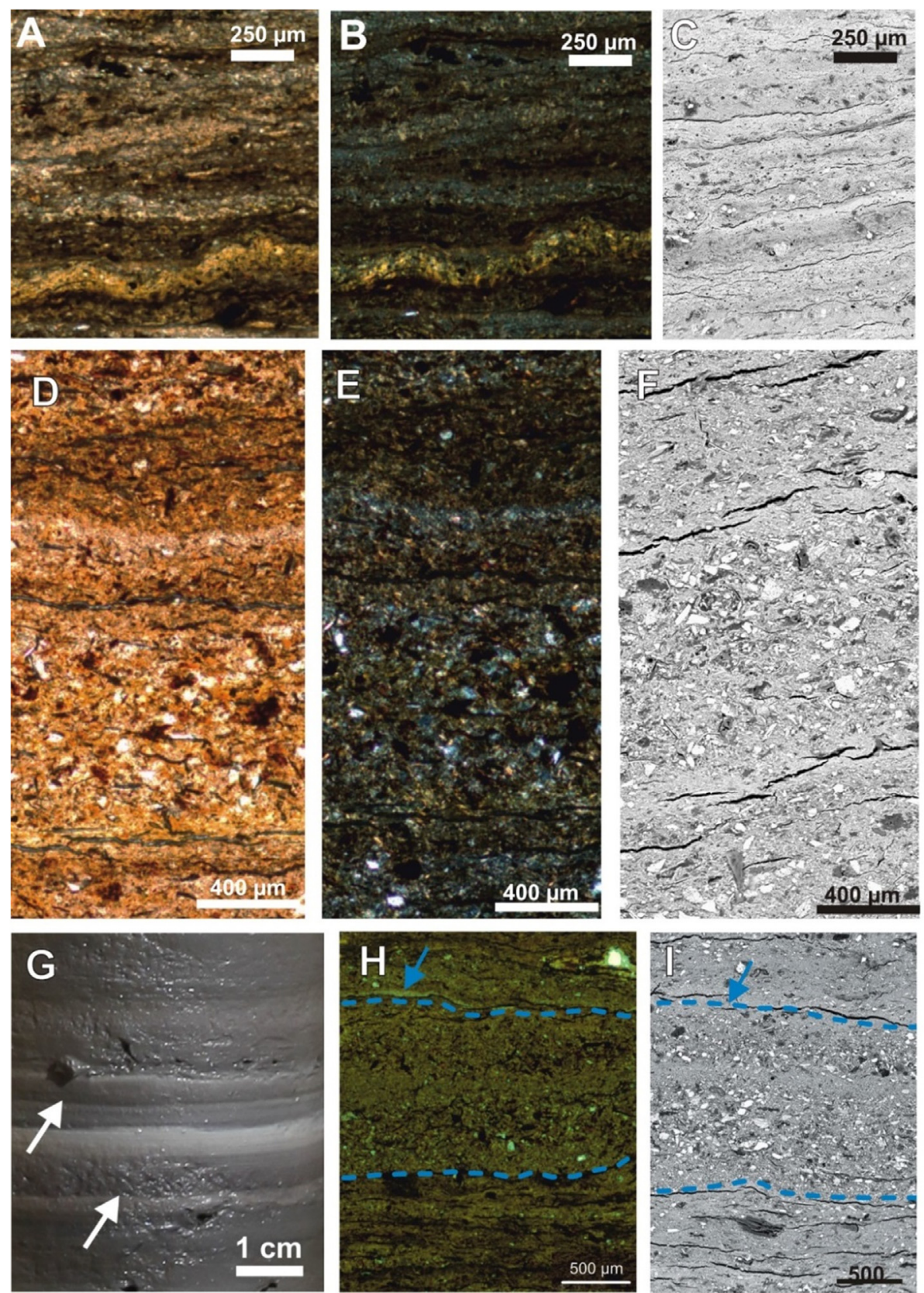

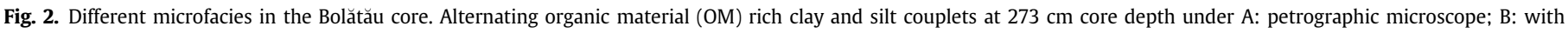

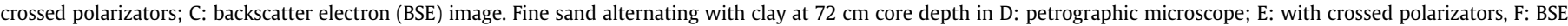


with crossed polars and I: BSE image.

achievable uniform temporal resolution is bidecadal from the current dataset. If a decadal-scale environmental history is desired to be deciphered from this sedimentary archive then finer sampling resolution (e.g. $0.5 \mathrm{~cm}$ slicing) is needed for future cores.

\subsection{Stable carbon isotope ratio of the bulk sediment}

Stable carbon isotopic composition ranged between -29.2 and $-26.5 \%$. Based on the distribution of $\delta^{13} \mathrm{C}$ values two main stages could be designated. Duplicates showed larger difference over the lower section of the core, whereas they closely matched above the $290 \mathrm{~cm}$ level (Fig. 6.). Mean difference of the duplicates below the $290 \mathrm{~cm}$ level $(\mathrm{n}=10)$ is $0.17 \%$, while above this level is only $0.08 \%$ o $(n=28)$. Another kind of breakpoint in the record is the
210-220 cm depth level. In addition, the samples showed a wider distribution between $\delta^{13} \mathrm{C}$ values of -27.2 and $-29.2 \%$ below the $\sim 210-220 \mathrm{~cm}$ depth level. Interesting to note that section of most depleted carbon isotope composition corresponds to the same section of the sediment where macroscopically visible vivianite patches were very abundant (Fig. 6). Above the $\sim 210-220 \mathrm{~cm}$ depth level $\delta^{13} \mathrm{C}$ values remained mostly between -28.2 and $-26.5 \%$.

The increased proportion of allochthonous sediment, documented by the decrease of organic and increase of minerogenic detrital material in the banded structure (Figs. 2 and 6), for the upper part of the core, however suggests an increase of allochthonous organic material input too, from the surrounding forest and the soil which coincides with the positive shift in the $\delta^{13} \mathrm{C}$ values. 

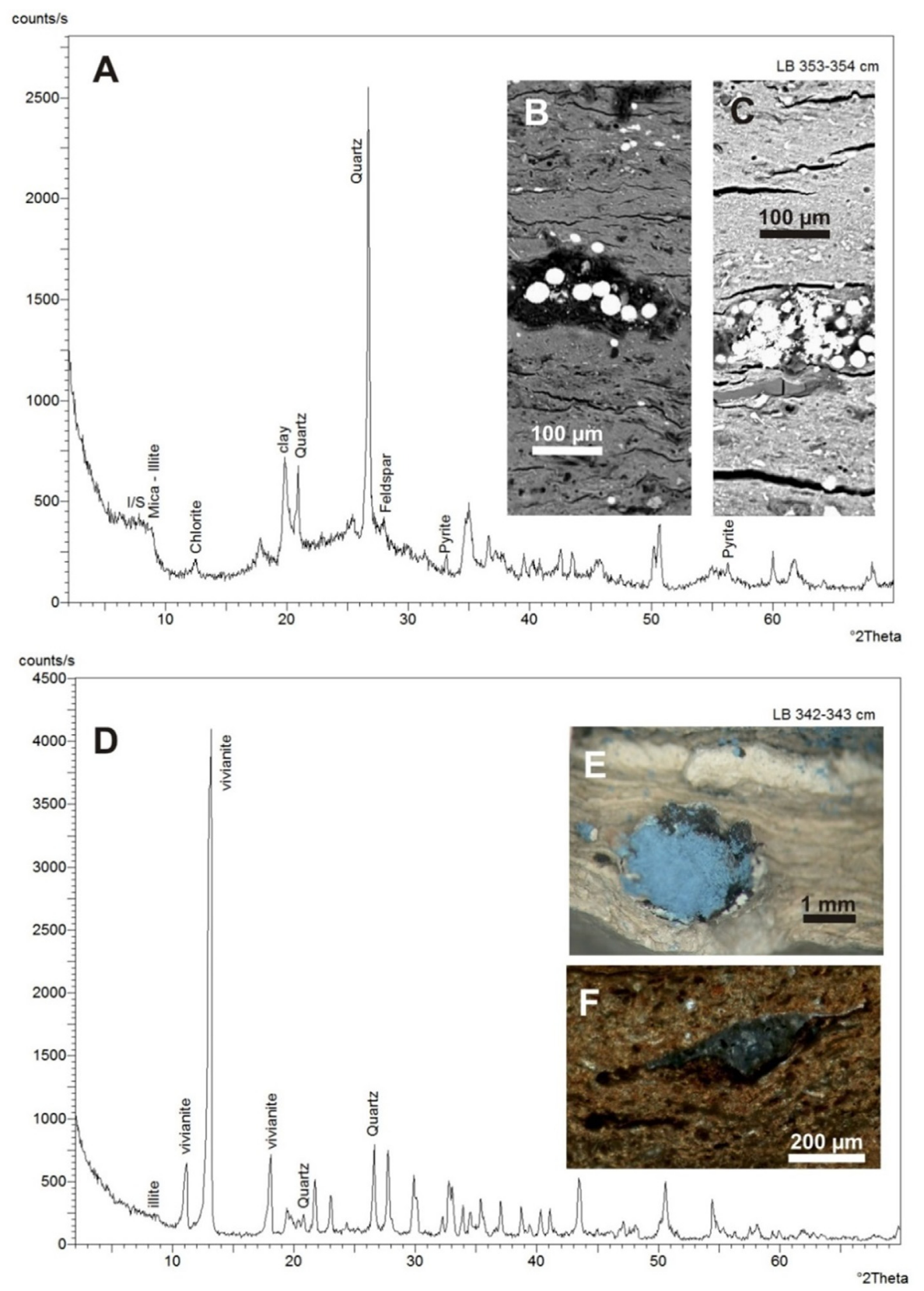

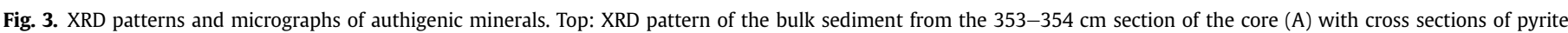

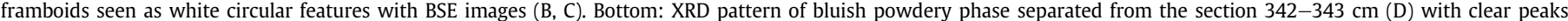
corresponding to vivianite. Inset photos show bluish microcrystalline aggregate around a seed under binocular (E) and in thin section under a petrographic (F) microscope.

\section{Discussion}

\subsection{Age of the lake}

The lake was first mentioned in a scientific study in AD 1964, and the first recorded historical reference to Lake Bolătău was in $\mathrm{AD}$ 1806 (Mindrescu et al., 2013); however, until now the age of the lake remained in doubt. The estimated age range (6593-4988 cal yr BP, 95.4\% probability range) obtained by projection of the age-depth model to the first lacustrine sediment layer $(387 \mathrm{~cm})$ is younger than the calibrated age of the wood fragment embedded in the underlying landslide body. Hence the beginning of the lacustrine sedimentation, and consequently the expected available time span of the paleoenvironmental archive can be estimated to $~ 5-6.5 \mathrm{ka}$. Assuming burial coinciding with the landslide related mass movement, calibrated radiocarbon results (6947-6783 cal yr BP, Table 2) from the wood fragment embedded in the landslide body indicate $\sim 6.8-7 \mathrm{ka}$ for the age of the landslide event of the basin genesis.

\subsection{Laminated structure - regular seasonal layers and irregular flood deposit}

Further proof will be collected (e.g. sediment trap) however we think the found alternating clay/silt and organic rich layers represent seasonal sediment units and their couplet represents annual layers. Regarding the dominance of warm season precipitation and the early summer discharge peak in the region we assume that 


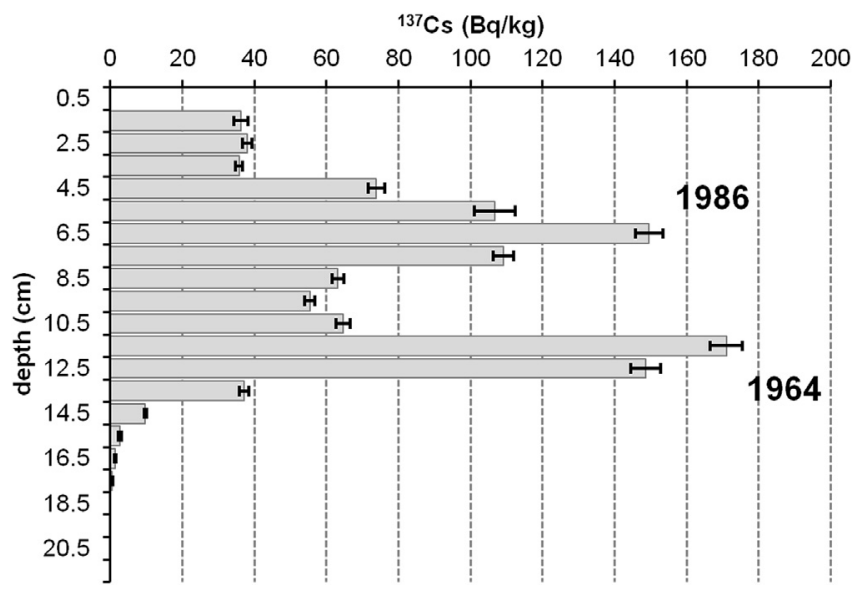

Fig. 4. Radiocaesium specific activities along the $20 \mathrm{~cm}$ topmost section of the Bolătău sediment sequence. Whiskers indicate the estimated analytical error. The distinct concentration peaks supposed to be coincident with AD 1986 (Chernobyl accident) and AD 1964 (north hemispheric fallout maximum) are indicated.



Fig. 5. Depth-age model of the Bolătău sediment sequence. Light (dark) shading shows the $95 \%$ (68\%) confidence range of the Bayesian model. Original and modelled probability density functions of the calibrated ${ }^{14} \mathrm{C}$ ages are plotted by white and dark grey, respectively. Uppermost $70 \mathrm{~cm}$ is enlarged and the assigned of ${ }^{137} \mathrm{Cs}$ marker horizons (see Fig. 4) are indicated by stars. The sample below the 'Bottom' position presents the calibration results of the ${ }^{14} \mathrm{C}$ analysis of the wood sample obtained from the landslide body.

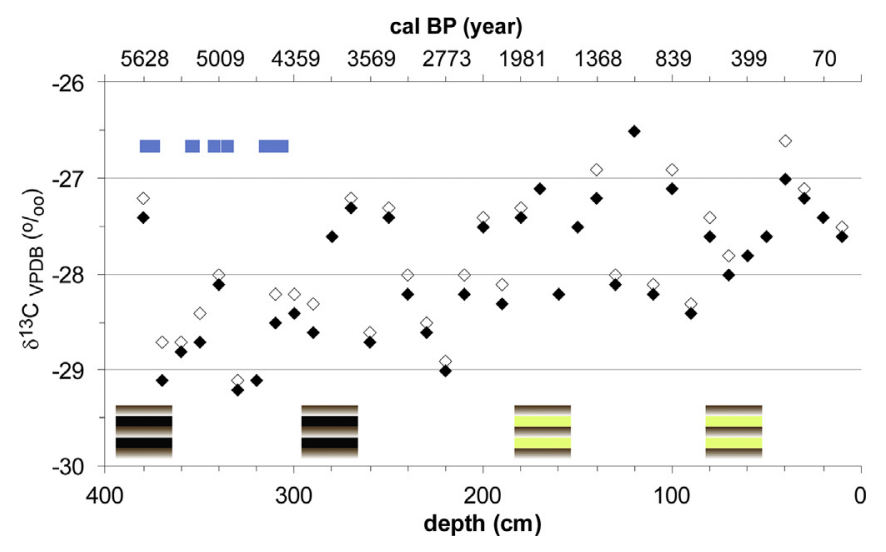

Fig. 6. Sedimentological characteristics and stable carbon isotope records of the Bolătău sediment sequence. Duplicate measurements are shown (open\&closed diamonds) for $\delta^{13} \mathrm{C}$ rather than the average value to visualize the systematically larger difference below the $290 \mathrm{~cm}$ level. Light blue squares above the $\delta^{13} \mathrm{C}$ points indicate samples with vivianite occurrence. Striped squares at the lower axis show the position of the petrographic thin sections. Clay-organic (brown-black) and clay-clastic (brownyellow) varves are indicated. (For interpretation of the references to colour in this figure legend, the reader is referred to the web version of this article.)

most of the allochthonous sediment input arrives this time to the lake. Consequently this is the time when the silt/fine sand laminae form with a sharp bottom boundary on the OM rich clay laminae. The minimum rainfall occurs in December and the lake is usually frozen from December to April (Rusu, 2002) therefore we assumed that this is the time of settling out of clay with organic particles.

This type of annually coupled sedimentation is widely observed (Ojala et al., 2012; Sturm and Matter, 1978). Based on the classification of Zolitschka (2007) we identified them as clastic varvite microfacies (Fig. 2A,B,C) and organic varvite microfacies (Fig. 2D,E,F). The occurrence of two types of varve microfacies in the lake suggests that the rate of sediment input slightly changed during the history of the lake. These changes probably reflect the changes in precipitation and discharge or the increasing/decreasing erosional rates.

The other microfacies, consisting of graded sand, is the result of a different process. Normal gradation represents the waning of the sediment laden underwater current but sometimes the graded laminae start with inversed grading (Fig. 2). This structure can occur when the velocity increases at the beginning of a turbidite underflow (waxing) (Mulder et al., 2001). Their light coloured clay cap indicates that these underflows occurred during episodic events, then clay could settle out from suspension in the calm water. Considering these processes, this microfacies can be interpreted as microturbidites. The episodic events can be either storm events or gravitational redepositions (Corella et al., 2014); however, as Corella et al. (2014) showed, mass movements are less likely to leave thin, graded structures.

The age-depth model suggests no major erosion or redeposition could be observed. Consequently the observed annually coupled lamination and the abundance of pyrite indicates no major bioturbation due to the closeness of the oxic-anoxic boundary to the surface of the sediment.

If we assume that the eroding effect of storms was negligible due to the winter (clay or algal) layers protecting the bottom surface from erosion, lamina counting could reveal the past frequency of storms in the lake and could also correct or validate the agedepth model. 


\subsection{Changes in the redox conditions-climate or lacustrine evolution?}

Pyrite is known to precipitate under specific pH and Eh conditions which cannot persist permanently in a small lake populated by macrophyte plants or vertebrates. Its precursor, iron monosulfide, however, is abundantly formed even on the $\mathrm{pH}$ of 7 if dissolved $\mathrm{Fe}^{2+}$ and sulfide are available. In this case after the process of burial in the presence of dissolved $\mathrm{H}_{2} \mathrm{~S}$ it is quickly replaced by the diagenetic end-member, pyrite (Rickard, 1975; Rickard and Luther, 1997). Waters containing free dissolved sulfide are anoxic or euxinic, therefore the presence of pyrite can be the indicator of such conditions even if it was not directly formed on them.

Pyrite was observed throughout the entire sediment sequence of Lake Bolătău and formed two texturally distinctive groups: micro-botryoidal aggregates as overgrowths on framboidal forms filling the voids (Fig. 3C) and separate framboids embedded in the bulk sediment (Fig. 3B). According to Wilkin et al. (1996) and Suits and Wilkin (1998) separate framboidal forms can be synsedimentary (precipitated from the water column or from the pore water in the upper $15 \mathrm{~cm}$ of the sediment) and the void-filling aggregates in the OM can be early-diagenetic forms. The presence of syn-sedimentary pyrite would mean that oxic-anoxic interface was often in the water column or close to the sediment surface. On the thin sections from 272 to $372 \mathrm{~cm}$ core depth these separate, framboidal forms with no overgrowth, and not attached to organic particles were more widely observed (Fig. 2). This feature coincides with the negative shift in the $\delta^{13} \mathrm{C}$ values and the abundant occurrence of macroscopically observable vivianite $(<306 \mathrm{~cm})$ in the core (Fig. 5). The latter also precipitates between $\mathrm{pH} 6-8$ and under reductive conditions (Dill and Techmer, 2009) which supports the anoxic origin of the observed syn-sedimentary pyrites.

Berner (1984) emphasized that the main factor controlling lacustrine sedimentary pyrite formation is the availability of sulphate. Sulphate reducing bacterial activity in similar lakes usually takes place a few centimetres under the sediment surface (Sass et al., 1997) therefore it is quite likely that the formation of framboidal pyrite followed the sediment surface and its intensity reflects the change in redox conditions near the sediment surface.

Based on the sedimentological data from the four thin sections the decreasing abundance of framboidal pyrite seems to correspond to the increase in maximum grain size and lamina thickness. It suggests that as the erosion in the catchment intensified, redox conditions became more oxic. This can be explained by the shift between an initial stage with limited or no drainage and calmer hydrodynamic conditions and a subsequent stage with drainage and more turbulent conditions. Regarding this breakpoint all differences of the two states (closed-basin at early stage, and overflow at the latter stage) of the lake must be considered in future efforts for paleoclimate reconstruction. Calibration based on recent conditions would be valid only for the upper $220 \mathrm{~cm}$ of the sediment corresponding to ca. the last three millennia.

\subsection{Major phases of the lacustrine evolution history of Lake Bolătău and correlation with other lakes}

By combining sedimentological observations (see Section 4.3.) and the stable carbon isotope records a preliminary evolution history can be conceived for the lake. A closed basin status can be assumed for first phase during which sedimentation was characterized by organic-varve deposition. Stable carbon isotope composition remained relatively depleted (except from the deepest sample) over the $370-290 \mathrm{~cm}$ range (from 5.5 to $4.2 \mathrm{ka}$ cal BP). The well distinguishable positive shift in $\delta^{13} \mathrm{C}$ record closely followed the disappearance of vivianite from the sediment corresponding to the most recent change in the lithology reported from the nearby Lake Steregoiu, (Björkman et al., 2003). Carbon isotope compositions were less depleted up to $250 \mathrm{~cm}(\sim 3.3-3.4 \mathrm{ka}$ cal BP) and returned to depleted level peaking at $220 \mathrm{~cm}(\sim 2.7-2.8 \mathrm{ka}$ cal BP). The outflow of the lake might have been inactive during this time. At present the outflow of the lake is a shallow brook therefore it is easy to imagine that a major water level fall could terminate the drainage. These interpretations and the represented time limits match quite well with the hydroclimatic changes of another nearby peat bog where wet conditions reconstructed from $3.57 \mathrm{ka}$ cal BP ceased due to an abrupt dry period from 3.39 to $3.03 \mathrm{ka}$ cal BP (Schnichten et al., 2006).

The increased influx of clastic material and variable but characteristically higher $\delta^{13} \mathrm{C}$ values from $210 \mathrm{~cm}(\sim 2.6 \mathrm{ka}$ cal BP) suggest that Lake Bolătău entered a new phase of evolution. The permanent overflow was probably established at this time, especially as independent records from the surroundings reported a significant shift to wet conditions around $\sim 2.55 \mathrm{ka}$ cal BP (Schnitchen et al., 2006; Skrzypek et al., 2009) suggesting that the increase in the Bolătău lake level and the initiation of the drainage might be the consequence of a regional precipitation increase.

The most remarkable positive shift in the $\delta^{13} \mathrm{C}$ values was found at around the $210-220 \mathrm{~cm}$ level in Lake Bolătău sediments, coeval with a major decrease in summer temperatures and precipitation in a pollen-based climate reconstruction in the nearby Gutaiului Mountains (Feurdean et al., 2008).

Additional good resemblance can be found in the fluctuation of the Bolătău $\delta^{13} \mathrm{C}$ record over this phase and environmental changes deduced from a peat bog record with suitable temporal resolution from southern Poland (Skrzypek et al., 2009). The highest $\delta^{13} \mathrm{C}$ value in the Lake Bolătău record dated to $\sim 1.07 \mathrm{ka}$ cal $\mathrm{BP}$ (120-121 cm depth range), for instance, perfectly coincides with the $\delta^{13} \mathrm{C}$ culmination of the SW Poland record at $1.1 \mathrm{ka}$ cal BP (Skrzypek et al., 2009).

These correspondences between the $\delta^{13} \mathrm{C}$ history of Lake Bolătău and the records of a relatively distant and two proximal lacustrine records imply a potential for future correlation. As an outlook, we expect that additional geochemical (e.g. $\mathrm{C} / \mathrm{N}$ ) data will complete and further improve our understanding on the paleoclimatic interpretation of the proxy data of Lake Bolătău sediment archive.

\section{Conclusion}

Microsedimentological analyses at four selected depth interval supported a seasonal deposition scheme of the Bolătău sedimentary record. The finely banded structure can be interpreted as organic and more clastic type varves at the lower and upper sections of the profile, respectively. An age-depth model fitted to eight AMS ${ }^{14} \mathrm{C}$ data was successfully validated by comparison with the ${ }^{137} \mathrm{Cs}$ marker horizons for the uppermost $20 \mathrm{~cm}$. Based on the numerical age data, the accumulation history for Lake Bolătău has been reconstructed. A major change in the hydrological regime (i.e. initiation of the overflow) is suspected to have occurred around 4.4-4.5 ka cal BP. Therefore, the initial lacustrine system cannot be analogue to the current regime. Limnological parameters measured in the current lake or transfer functions established between proxies from the most recent sedimentary sections and coeval instrumental hydrological/meteorological variables must treated with caution if they are to be utilized for the deepest section. Major fluctuations found in the coarsely sampled $(5 \mathrm{~cm})$ stable carbon isotope data showed remarkable correspondence with nearby well dated proxy data, which suggest that the Bolătău sediment record preserves environmental signals with a broader regional relevance. Together, the timescale and accumulation reconstruction provide the necessary basis for further multiproxy analysis of the records 
from Bolătău.

The first detailed microsedimentological and geochronological analysis proved the great potential of the Bolătău sediment archive for future high resolution paleolimnological investigations. As a useful experience, it is proved that decadal temporal resolution is achievable from Lake Bolătău sediment archive, although finer sampling $(0.5 \mathrm{~cm})$, is needed at least below $130 \mathrm{~cm}$. The fact that the lake is located in a region where such records are scarce or practically lacking provides further importance to this archive. Furthermore, it might invite more research effort to the other Bukovinian landslide-dammed lakes.

\section{Acknowledgements}

Thanks for support from "Lendület" program of the Hungarian Academy of Sciences (LP2012-27/2012). MM and GI acknowledge the project PN-II-RU-TE-2012-3-0386 (UEFISCDI Romania).This is contribution No.25. of $2 k a$ Palæoclimatology Research Group.

\section{Appendix A. Supplementary data}

Supplementary data related to this article can be found at http:// dx.doi.org/10.1016/j.quageo.2015.10.007.

\section{References}

Akinyemi, O., Hutchinson, S.M., Mîndrescu, M., Rothwell, J.J., 2013. Lake sediment records of atmospheric pollution in the Romanian Carpathians. Quat. Int. 293, 105-113.

Alhajji, E., Ismail, I.M., Al-Masri, M.S., Salman, N., Al-Haleem, M.A., Doubal, A.W. 2014. Sedimentation rates in the Lake Qattinah using ${ }^{210} \mathrm{~Pb}$ and ${ }^{137} \mathrm{Cs}$ as geochronometer. Geochronometria 41 (1), 81-86.

Anderson, N.J., 1995. Using the past to predict the future: lake sediments and the modelling of limnological disturbance. Ecol. Model 78, 149-172.

Anderson, N.J., Battarbee, R.W., 1994. Aquatic community persistence and variability: a palaeolimnological perspective. In: Gillier, P.S., Hildrew, A.G. Raffelli, D. (Eds.), Aquatic Ecology: Scale, Pattern and Process. Blackwell, Oxford, pp. 233-259.

Appleby, P.G., 2008. Three decades of dating recent sediments by fallout radionuclides, a review. Holocene 18 (1), 83-93. http://dx.doi.org/10.1177/ 0959683607085598.

Begy, R., Cosma, C., Timar, A., 2009. Recent changes in Red Lake (Romania) sedimentation rate determined from depth profiles of ${ }^{210} \mathrm{~Pb}$ and ${ }^{137} \mathrm{Cs}$ radioisotopes. J. Environ. Radioact. 100 (8), 644-648. http://dx.doi.org/10.1016/ j.jenvrad.2009.05.005.

Berner, R.A., 1984. Sedimentary pyrite formation: an update. Geochim. Cosmochim. Acta 48, 605-615.

Birks, H.H., Birks, J.H.B., 2006. Multi-proxy studies in palaeolimnology. Veg. Hist. Archaeobotany 15, 235-251.

Björkman, L., Feurdean, A., Wohlfarth, B., 2003. Late glacial and holocene vegetation development at steregoiu in the gutaiului mountains, NW Romania. Rev. Palaeobot. Palynol. 124, 79-111.

Blebea-Apostu, A.M., Radulescu, I., Margineanu, R., Ionita, I., Popescu, I.V., 2012. Assessment of sedimentation rate through the use of anthropogenic ${ }^{137} \mathrm{Cs}$ radionuclide. Rom. Rep. Phys. 64 (1), 211-220.

Bronk Ramsey, C., 2009. Bayesian analysis of radiocarbon dates. Radiocarbon 51 (1), $337-360$.

Buczkó, K., Magyari, E.K., Bitušík, P., Wacnik, A., 2009. Review of dated late Quaternary palaeolimnological records in the Carpathian Region, east-centra Europe. Hydrobiologia 208, 3-28.

Cohen, A.S., 2003. Paleolimnology. The History and Evolution of Lake Systems. Oxford University Press, Oxford.

Coplen, T.B., Brand, W.A., Gehre, M., Gröning, M., Meijer, H.A.J., Toman, B. Verkouteren, R.M., 2006. New guidelines for $\delta^{13} \mathrm{C}$ measurements. Anal. Chem. 78 (7), 2439-2441.

Corella, J.P., Benito, G., Rodriguez-Lloveras, X., Brauer, A., Valero-Garcés, B.L., 2014. Annually-resolved lake record of extreme hydro-meteorological events since AD 1347 in NE Iberian Peninsula. Quat. Sci. Rev. 93, 77-90.

De Cort, M., Dubois, G., Fridman, S.D., Gemenchuk, M.G., Izrael, Y.A., Jansses, A., Jones, A.R., Kelly, G.N., Kvasnikova, E.V., Matveenko, I.I., Nazarov, I.M., Pokumeiko, Y.M., Sitak, V.A., Stukin, E.D., Tabachny, L.Y., Tsaturov, Y.S. Avdyushin, S.I., 1998. Atlas of Caesium Deposition on Europe after the Chernobyl Accident. EUR report nr. 16733. EC. Office for Official Publications of the European Communities, Luxembourg.

Cosma, C., 2002. Some aspects of radioactive contamination after chernobyl accident in Romania. J. Radioanal. Nucl. Chem. 251, 221-226.

Dill, H.G., Techmer, A., 2009. The geogene and anthropogenetic impact on the formation of per descensum vivianite-goethite-siderite mineralization in Mesozoic and cenozoic siliciclastic sediments in SE Germany. Sediment. Geol. 217, 95-111.

Feurdean, A., Klotz, S., Mosbrugger, V., Wohlfarth, B., 2008. Pollen-based quantitative reconstruction of Holocene climate variability in NW Romania. Palaeogeogr. Palaeoclimatol. Palaeoecol. 260, 494-504.

Georgescu, D., Georgescu, L., 1964-1965. Observaţii asupra unor fenomene fizicogeografice în zona şisturilor negre din bazinul superior al văii Moldova (NV de Câmpulung). Dări Seamă ale Sedintelor LII/1, 395-405.

Grădinaru, I., Iosep, I., Pociask-Karteczka, J., Brancelj, A., Mácha, P., 2012. Study of the occurrence and distribution of "Iezer" and "Bolătău“- based toponyms in Romania and their counterparts from Poland, the Czech Republic and Slovenia. Georeview 21, 68-79.

IAEA, 1991. The International chernobyl Project: an overview, assessment of radiological consequences and evaluation of protective measures. Report by an International Advisory Committee. IAEA, Vienna, Austria. Soil Use Manag. 7, 169-176.

McKinney, C.R., McCrea, J.M., Epstein, S., Allen, A., Urey, H.C., 1950. Improvements in mass spectrometers for the measurement of small differences in isotope abundance ratios. Rev. Sci. Instrum. 21, 724-730.

Mîndrescu, M., Cristea, A.I., Florescu, G., 2010a. Water quality and ecology of the Iezer and Bolătău lakes. Rom. J. Limnol. Lakes, Reserv. Ponds 4, 117-130.

Mîndrescu, M., Cristea, A.I., Hutchinson, S.M., 2010b. Bathymetrical and sedimentological changes of glacial lake Ştiol, Rodna Massif. Carpath. J. Earth Environ. Sci. 5 (1), 57-65.

Mîndrescu, M., Cristea, A.I., Hutchinson, S.M., Florescu, G., Feurdean, A., 2013. Interdisciplinary investigations of the first reported laminated lacustrine sediments in Romania. Quat. Int. 239, 219-230. http://dx.doi.org/10.1016/ j.quaint.2012.08.2105.

Molnár, M., Rinyu, L., Janovics, R., Major, I., Veres, M., 2012. Az új debreceni C-14 laboratórium bemutatása (Introduction of the new AMS C-14 laboratory in Debrecen). Archeometriai Mủhely 9, 147-160.

Molnár, M., Janovics, R., Major, I., Orsovszki, J., Gönczi, R., Veres, M., Leonard, A.G., Castle, S.M. Lange, T.E., Wacker, L., Hajdas, I., Jull, A.J.T., 2013a. Status report of the new AMS C-14 sample preparation lab of the Hertelendi laboratory of Environmental Studies, Debrecen, Hungary. Radiocarbon 55, 665-676.

Molnár, M., Rinyu, L., Veres, M., Seiler, M., Wacker, L., Synal, H.-A., 2013b. EnvironMICADAS: a mini 14C-AMS with enhanced gas ion source interface in the Hertelendi laboratory of Environmental Studies (HEKAL). Hung. Radiocarb. 55, 338-344. http://dx.doi.org/10.2458/azu_js_rc.55.16331.

Mulder, T., Migeon, S., Savoye, B., Faugeres, J.-C., 2001. Inversely graded turbidite sequences in the deep Mediterranean: a record of deposits from floodgenerated turbidity currents? Geo-Marine Lett. 21, 86-93.

Ojala, F., Zolitschka, B., Lamoureux, B., 2012. Characteristics of sedimentary varve chronologies - a review. Quat. Sci. Rev. 43, 45-60.

Reimer, P.J., Bard, E., Bayliss, A., Beck, J.W., Blackwell, P.G., Bronk Ramsey, C., Grootes, P.M., Guilderson, T.P., Haflidason, H., Hajdas, I., Hatte, C., Heaton, T.J., Hoffmann, D.L., Hogg, A.G., Hughen, K.A., Kaiser, K.F., Kromer, B., Manning, S.W. Niu, M., Reimer, R.W., Richards, D.A., Scott, E.M., Southon, J.R., Staff, R.A., Turney, C.S.M., van der Plicht, J., 2013. IntCal13 and Marine13 radiocarbon age calibration curves 0-50,000 years cal BP. Radiocarbon 55 (4), 1869-1887.

Rickard, D.T., 1975. Kinetics and mechanism of pyrite formation at low-temperatures. Am. J. Sci. 275, 636-652.

Rickard, D.T., Luther III, G.W., 1997. Kinetics of pyrite formation by the H2S oxidation of iron(II) monosulfide in aqueous solutions between $25^{\circ} \mathrm{C}$ and $125^{\circ} \mathrm{C}$ : the mechanism. Geochim. Cosmochim. Acta 61, 135-147.

Rinyu, L., Molnár, M., Major, I., Nagy, T., Veres, M., Kimák, Á., Wacker, L., Synal, H.-A., 2013. Optimization of sealed tube graphitization method for environmental 14C studies using MICADAS. Nucl. Instrum. Methods Phys. Res. B 294, 270-275.

Ritchie, J.C., McHenry, J.R., 1990. Application of radioactive fallout cesium-137 for measuring soil erosion and sediment accumulation rates and patterns: a review. J. Environ. Qual. 19, 215-233.

Rusu, C., 2002. Masivul Rarău. Studiu de geografie fizică. Editura Academiei Române, Bucuresti.

Sass, H., Heribert, C., Babenzien, H.-D., 1997. Vertical distribution of sulfate-reducing bacteria at the oxic-anoxic interface in sediments of the oligotrophic Lake Stechlin. FEMS Microbiol. Ecol. 22, 245-255.

Schnitchen, C., Charman, D.J., Magyari, E., Braun, M., Grigorszky, I., Tóthmérész, B., Molnár, M. Szántó, Zs, 2006. Reconstructing hydrological variability from testate amoebae analysis in Carpathian peatlands. J. Paleolimnol. 36 (1), 1-17.

Skrzypek, G., Baranowska-Kącka, A., Keller-Sikora, A., Jędrysek, M.O., 2009. Analogous trends in pollen percentages and carbon stable isotope composition of Holocene peat - possible interpretation for palaeoclimate studies. Rev. Palaeobot. Palynology 156, 507-518.

Smol, J.P., 1992. Paleolimnology; an important tool for effective ecosystem management. J. Aquat. Ecosyst. Health 1, 49-58.

Smol, J.P., 2008. Pollution of Lakes and Rivers: a Palaeoenvironmental Perspective, second ed. Blackwell, London.

Smol, J.P., Birks, H.J.B., Last, W.M. (Eds.), 2001a. Tracking Environmental Change Using Lake Sediments. Terrestrial, Algal and Siliceous Indicators, vol. 3. Kluwer, Dordrecht.

Smol, J.P., Birks, H.J.B., Last, W.M. (Eds.), 2001b. Tracking Environmental Change Using Lake Sediments. Zoological Indicators, vol. 4. Kluwer, Dordrecht.

Sofer, Z., 1980. Preparation of carbon dioxide for stable carbon isotope analysis of petroleum fractions. Anal. Chem. 52 (8), 1389-1391. 
Stuiver, M., Polach, H.A., 1977. Reporting of C-14 data - discussion. Radiocarbon 19, 355-363.

Sturm, M., Matter, A., 1978. Turbidites and varves in Lake Brienz (Switzerland): deposition of clastic detritus by turbidity currents. In: Matter, A., Tucker, M.E. (Eds.), Modern and Ancient Lake Sediments, International Association of Sedimentologists, Spec. Publ. 2, pp. 145-167.

Suits, N.S., Wilkin, R.J., 1998. Pyrite formation in the water column and sediments of a Meromictic Lake. Geology 26, 1099-1102.

Săndulescu, M., 1984. Geotectonica României. Editura Tehnică, București.

Wilkin, R.T., Barnes, H.L., Brantley, S.L., 1996. The size distribution of framboidal pyrite in modern sediments: an indicator of redox conditions. Geochim. Cosmochim. Acta 60, 3897-3912.

Zolitschka, B., 2007. Varved lake sediments. In: Elias, S.A. (Ed.), Encyclopedia of Quaternary Science. Elsevier, Amsterdam, pp. 3105-3114. 